\title{
Recruitment challenges in surgical trials: lessons from the crisp trial
}

\author{
$\mathrm{K}$ Pike $^{1 *}, \mathrm{GD}$ Angelini ${ }^{1}, \mathrm{BC}$ Reeves ${ }^{1}$, DP Taggart ${ }^{2}$, CA Rogers $^{1}$ \\ From 2nd Clinical Trials Methodology Conference: Methodology Matters \\ Edinburgh, UK. 18-19 November 2013
}

\section{Background}

The results of surgical trials are often challenged because of concerns about the experience and skill of the surgeons taking part. When well-established alternative surgical procedures exist, individual surgeons are usually more proficient in, and favour, a single approach. Conventional within-surgeon randomisation requires surgeons to be proficient in both procedures, which may skew the surgical expertise towards one technique. Expertise-based randomisation overcomes this limitation. We describe our experience of implementing expertisebased randomisation in the context of the CRISP trial to compare on-pump and off-pump CABG in high-risk patients.

\section{Methods}

Non-emergency patients with a EuroSCORE $>=5$ were eligible to participate. Elective patients were approached and consented at the pre-assessment clinic. Information was faxed to urgent patients waiting in nearby "feeder" hospitals and they were consented on transfer to the specialist centre. Following randomisation surgery was arranged with the appropriate expert surgeon.

\section{Results}

The trial struggled to recruit. Barriers to recruitment included (a) patients unwilling to be randomised to a surgeon they had not met; (b) surgeons unwilling to "share" patients; (c) unavailability of expert surgeon to operate within NHS target time; (d) insufficient time to arrange surgery. After 18 months the trial was closed prematurely. 106 patients had been recruited from a study target of 5200 randomised patients.

'University of Bristol, Bristol, UK

Full list of author information is available at the end of the article

\section{Conclusion}

Expertise-based randomisation may not be possible in a tertiary referral setting in the UK and may be more easily achieved overseas where healthcare is organised differently. Including integrated qualitative research to gain full understanding of trial issues may have increased patient participation.

\section{Authors' details}

${ }^{1}$ University of Bristol, Bristol, UK. ${ }^{2}$ University of Oxford, Oxford, UK.

Published: 29 November 2013

doi:10.1186/1745-6215-14-S1-P27

Cite this article as: Pike et al:: Recruitment challenges in surgical trials: lessons from the crisp trial. Trials 2013 14(Suppl 1):P27.
Submit your next manuscript to BioMed Central and take full advantage of:

- Convenient online submission

- Thorough peer review

- No space constraints or color figure charges

- Immediate publication on acceptance

- Inclusion in PubMed, CAS, Scopus and Google Scholar

- Research which is freely available for redistribution
C Biomed Central

\section{Biomed Central}

